\title{
Antioxidant activities of soymilk added with green tea and rosemary extract
}

\author{
Ji-yeon Ryu ${ }^{1}$, YeonWoo Song ${ }^{2}$, Jeong Yong Moon ${ }^{2}$, Neung-Jae Jun ${ }^{3}$, \\ Somi Kim Cho ${ }^{1,2 *}$ \\ ${ }^{1}$ School of Biomaterials Sciences and Technology, College of Applied Life Sciences, SARI, Jeju National University, \\ Jeju 63243, Korea \\ ${ }^{2}$ Subtropical/tropical organism gene bank, Jeju National University, Jeju 63243, Korea \\ ${ }^{3}$ Jejumorning Co., Ltd., Jeju 63300, Korea
}

\section{녹차와 로즈마리 추출물을 첨가한 두유의 항산화 활성}

\author{
류지연 ${ }^{1} \cdot$ 송연우 $^{2} \cdot{\text { 문정 }^{2}}^{2} \cdot$ 전능재 $^{3} \cdot$ 김소미 ${ }^{1,2 *}$ \\ ${ }^{1}$ 제주대학교 바이오소재공학과, ${ }^{2}$ 아열대· 열대생물유전자은행센터, ${ }^{3}$ (주) 제주아침
}

\begin{abstract}
The objective of this study was to compare antioxidant activities of green tea, rosemary, lemon and bamboo leaves extracts using three different extraction methods $\mathbf{8 0} \%$ ethanol sonication extraction, distilled water autoclave extraction, distilled water extraction at room temperature). As a result, green tea and rosemary extracts showed relatively high antioxidant activities compared with those of lemon and bamboo leaves. These green tea and rosemary extracts were subsequently added to soymilk and their mixtures were examined for antioxidant activities. Soymilk added with $10 \%$ green tea distilled water autoclave extracts and distilled water at room temperature extracts showed relatively high DPPH, 85.09 $\pm 2.26 \%, 84.38 \pm 1.97 \%$, and ABTS radical scavenging activities, $73.43 \pm 2.78 \%, 81.34 \pm 4.78 \%$, respectively. On the other hand, soymilk added with $10 \%$ rosemary distilled water autoclave extracts showed remarkably higher DPPH radical scavenging activity while their ABTS radical scavenging ability was similar to that of non-added soymilk. In conclusion, our results suggest that the addition of green tea distilled water autoclave extracts, distilled water at room temperature extracts and rosemary distilled water autoclave extracts to soymilk could contribute to the development of added value soymilk products with increased antioxidant activities.
\end{abstract}

Key words : antioxidant, green tea, jeju island, rosemary, soymilk

\section{서 론}

대두(Glycine max L. Merrill)는 한국, 중국, 일본, 동남아 시아에서 수세기 동안 다양한 형태로 단백질과 지질을 공급 하는 원료로 이용되어져 왔다(1). 또한, 대두는 isoflavone, phytosterol, 식이섬유 등이 풍부하고, 식물성 고단백 식품으

*Corresponding author. E-mail : phd.kim.somi@gmail.com Phone : 82-64-754-3348, Fax : 82-64-756-3351

Received 2 August 2017; Revised 25 August 2017; Accepted 12 October 2017.

Copyright (c) The Korean Society of Food Preservation. All rights reserved.
로 암을 비롯하여 심혈관계 질환 등 많은 성인병 치료 가능 성에 대해 보고되고 있다(2). 대두를 이용한 식품으로는 된장, 고추장 등의 발효식품과 두유, 콩나물 등의 비발효식 품으로 구분되어진다. 이들 중 두유는 대두를 이용한 대표 적인 가공품으로 필수 아미노산, 필수 지방산, 비타민 등을 다량으로 함유하고 있으며, 철, 인, 칼륨 등의 무기질이 풍부 하다. 또한, 콜레스테롤과 유당이 적어 식물성 건강음료로 인식되고 있으며 소비계층 또한 매우 다양하다(3).

현재 시중에서 판매되고 있는 두유의 종류는 순수 두유 제품, 검은콩, 오트밀 두유, 칼슘 강화 두유, 검은깨 첨가 두유 등이 있으며, 기능성 식품 첨가 두유와 관련한 연구로 는 자색고구마를 첨가한 두유요구르트(4), 인삼 첨가 발효 
두유(5), 쌀알 첨가 두유(6), 스테비아 잎 분말을 첨가한 두유(7), 메밀싹 첨가 두유(8) 등이 있다. 그러나 항산화 소재를 선별하여 두유에 첨가한 연구는 거의 없는 실정이 며, 기능성 소재를 첨가한 연구 대다수 두유의 성분변화와 관능검사에 대한 연구로 항산화 소재를 첨가한 두유의 연구 가 필요하다.

생체 내에서 산화로 인해 발생하게 되는 활성산소종 (reactive oxygen species)은 세포 내 기관의 정상적인 대사 및 세포질 내 효소들에 의하여 자연적으로 발생되며, 세포 내 적당한 양이 존재할 경우 여러 세포 반응을 조절하는 신호분자가 된다. 하지만 과량의 활성산소종은 DNA와 단 백질을 불활성화 시키고, 세포 생체막의 구성 성분인 불포 화 지방산을 공격하여 생체기능을 저하시킨다. 이로 인해 노화를 유발하며 암, 심장병과 같은 여러 질환의 원인이 된다. 항산화제(antioxidants)는 이러한 유해한 활성산소에 의해 발생되는 지질의 과산화, 세포막 및 적혈구 파괴, 발암 물질의 생성, 세포의 노화 등의 작용을 억제함과 동시에 식품 보존성 향상에도 이용된다.

현대 사회에서 건강 및 웰빙에 대한 소비자 욕구가 증가 함에 따라 안전성과 친환경적인 고부가가치 식품의 글로벌 마켓이 계속 확대될 전망이며 이에 따라 생체 내 항산화 방어시스템을 간접적으로 증가시키거나 직접적으로 활성 산소종을 소거시키면서 인체에 부작용이 없는 식물 유래의 천연 항산화제 개발을 위한 연구가 활발히 진행되고 있다 $(9,10)$.

두유에 첨가 했을 때 거부감이 없으며 항산화 활성이 뛰어난 소재로서는 녹차, 로즈마리, 레몬 잎, 조릿대 잎 등을 들 수 있다. 녹차(Camellia sinensis L.)는 카테킨 화합물 등 폴리페놀 화합물을 많이 함유하고 있으며, 항산화, 항암, 당뇨완화 등에 효과가 있다(11). 로즈마리(Rosmarinus officinalis L.)는 식용, 미용, 약용, 향료 등 다양한 부분에 유용하게 이용되고 있으며, 시네올, 캠퍼 등 함유되어있으 며, 항산화 활성과 항응고 활성을 보인다(12). 레몬(Citrus limon L.)은 구연산과 비타민 $\mathrm{C}$ 를 함유하고 있으며 노화방 지와 살균작용 등 다양한 활성을 갖고 있다(13). 조릿대 (Sasa quelpaertensis)는 페놀성 물질과 플라본 배당체 성분 이 함유되어 있으며, 항산화, 살균, 항진균 활성이 있으며 또한 고혈압, 발한 등의 치료에도 사용된다(14).

본 연구에서는 제주에서 재배되고 있는 녹차, 로즈마리, 레몬 잎, 조릿대 잎을 식품 공정상 이용이 가능한 물과 에탄 올을 추출 용매로 이용하여 다양한 조건으로 추출하고 각 추출물의 항산화 활성을 비교하였다. 이들 중 항산화 활성 이 우수한 식물추출물을 선발하고 이를 두유에 첨가 시, 항산화 활성이 증대된 두유제품 개발이 가능할 것으로 기대 되는 원료의 추출 조건을 확인하였다.

\section{재료 및 방법}

실험재료 및 시약

본 연구에서 재료로 사용한 녹차, 로즈마리. 레몬 잎, 조 릿대 잎은 제주도에서 2015년 8월중에 채취하였으며, 세척, 건조한 후 사용하였다. 두유는 (주)제주아침에서 2015년 제조한 두유를 사용하였다. Folin-Ciocalteu's reagent, Gallic acid, Rutin, 2,2-diphenyl-1-picrylhydrazyl(DPPH), 2,2'-azino-bis (3-ethylbenzothiazoline-6-sulphonic acid) diammonium salt (ABTS)는 Sigma Chemical Co.(St. Louis, MO, USA)에서 구입하여 사용하였다.

\section{추출물 제조}

식물 잎 추출물 제조

식물 잎 추출물은 세 가지 추출조건으로 제조하였다, 시 료에 각 50 배의 추출 용매를 가한 후 에탄올 초음파 추출 (80\% ethanol sonication extraction)은 sonicator로 15분씩 3 회 반복 추출하였고, 증류수 가압 가열 추출(distilled water autoclave extraction)은 autoclave(SX700, Tomy, Tokyo, $\mathrm{Japan}$ )를 이용하여 $121^{\circ} \mathrm{C}$ 에서 20 분간 추출하였으며, 증류 수 상온 추출(distilled water extraction at room temperature) 은 12 시간 동안 상온정치 추출하였다. 각 추출물은 여과지 로 여과한 후 rotary vacuum evaporator로 $50^{\circ} \mathrm{C}$ 에서 감압 농축한 후 동결 건조하여 사용하였다.

\section{녹차, 로즈마리 추출물 첨가 두유 제조}

녹차와 로즈마리 추출물을 $1 \%, 10 \%$ 첨가한 두유를 동결 건조한 후 $80 \%$ 메탄올을 넣고 sonicator로 15 분씩 3 회 반복 추출하였다. 이후 여과지로 여과한 후 rotary vacuum evaporator로 $50^{\circ} \mathrm{C}$ 에서 감압 농축한 후 동결 건조하여 사용 하였다.

\section{총 폴리페놀 함량}

총 폴리페놀 함량은 Cheung 등(15)의 방법을 약간 변형하 여 증류수 $1.375 \mathrm{~mL}$ 에 $125 \mu \mathrm{L}$ 의 시료를 넣은 후 $0.5 \mathrm{~mL}$ Folin-ciocalteu's reagent를 넣고 4 분 후에 $1 \mathrm{~mL}$ 의 $\mathrm{Na}_{2} \mathrm{CO}_{3}$ 를 가한 다음 상온에서 30 분 동안 정치하여 반응시켰다. 그 후 분광광도계(Sunrise, Tecan, Salzburg, Austria)를 이용하 여 $700 \mathrm{~nm}$ 에서 흡광도를 측정하였다. 함량은 gallic acid equivalents(mg GAE/g)로 나타내었다.

\section{총 플라보노이드 함량}

총 플라보노이드 함량은 Zhishen 등(16)의 방법을 변형하 여 측정하였다. 증류수 $80 \mu \mathrm{L}$ 에 시료 $40 \mu \mathrm{L}$ 를 넣은 후 5\% $\mathrm{NaNO}_{2} 6 \mu \mathrm{L}$ 를 첨가하여 5 분간 반응시킨 후 $10 \% \mathrm{AlCl}_{3}$ $12 \mu \mathrm{L}$ 를 혼합하여 6분간 반응시킨 다음 $1 \mathrm{~N} \mathrm{NaOH} 40 \mu \mathrm{L}$ 를 첨가한다. 그 후 증류수 $42 \mu \mathrm{L}$ 를 넣고 앙금이 생기지 않도록 
잘 섞어준 후 분광광도계(Sunrise, Tecan, Salzburg, Austria) 를 이용하여 $510 \mathrm{~nm}$ 에서 흡광도를 측정하였다. 함량은 rutin equivalents(mg RE/g)로 나타내었다.

\section{$\mathrm{DPPH}$ 라디칼 소거능 측정}

$\mathrm{DPPH}$ 라디칼 소거능 측정은 기존에 보고된 방법 $(17,18)$ 을 토대로 하여 수행하였다. DPPH 라디칼 용액은 $\mathrm{DPPH}$ 를 $200 \mu \mathrm{M}$ 로 에탄올에 용해시켜 준비하였고, 96-well plate에 시료를 농도별로 $40 \mu \mathrm{L}$ 씩 분주하고 $200 \mu \mathrm{M} \mathrm{DPPH}$ radical 용액 $160 \mu \mathrm{L}$ 를 첨가한 후 30 분간 $37^{\circ} \mathrm{C}$ incubator에서 반응시 켰다. 반응이 끝나면 분광광도계(Sunrise, Tecan, Salzburg, Austria)를 이용하여 $517 \mathrm{~nm}$ 에서 흡광도를 측정하였다. 양 성대조군으로는 catechin을 사용하였다.

DPPH radical scavenging activity $(\%)=\left(1-\frac{\text { 시료의 흡광도 }}{\text { 대조구의 흡광도 }}\right) \times 100$

\section{Electron spin resonance(ESR) spectrometer를 이용한 DPPH 라디칼 소거능 측정}

추출물을 첨가한 두유의 경우 ESR spectrometer(JESFA200, JEOL, Tokyo, Japan)를 이용하여 DPPH 라디칼 소 거능을 측정하였다. 이는 기존에 보고된 방법(19)을 토대로 하여 수행하였다. DPPH 라디칼 용액은 DPPH를 $60 \mu \mathrm{M}$ 로 에탄올에 용해시켜 준비하였으며, 튜브에 시료를 농도별로 $30 \mu \mathrm{L}$ 씩 넣고 $60 \mu \mathrm{M} \mathrm{DPPH}$ 라디칼 용액 $30 \mu \mathrm{L}$ 를 첨가한 후 2 분간 상온에서 반응시켰다. 반응이 끝나면 $\mathrm{ESR}$ spectrometer(JES- FA200, JEOL, Tokyo, Japan)를 이용하여 흡광도를 측정하였다. 측정조건은 magnetic field 336.000 $\mathrm{mT}$, power $5 \mathrm{mM}$, sweep time 30초, sweep width $10 \mathrm{mT}$, frequency $9.43 \mathrm{GHz}$, modulation width $0.2 \mathrm{mT}$, amplitude 500 , time constant 0.03 초이며, 양성 대조군으로는 catechin 을 사용하였다.

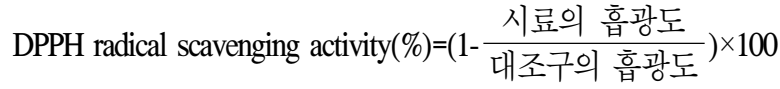

\section{ABTS 라디칼 소거능 측정}

ABTS 라디칼 소거능 측정은 기존에 보고된 방법(20)을 변형하여 수행하였으며, ABTS 라디칼 용액은 $7 \mathrm{mM} \mathrm{ABTS}$ 와 $2.45 \mathrm{mM} \mathrm{K} 2 \mathrm{~S}_{2} \mathrm{O}_{8}$ 를 혼합해 20시간 동안 암소에 보관하여 준비하였으며, 흡광도가 $0.700 \pm 0.005$ 에 도달하게 증류수로 희석하여 사용하였다. 큐벳에 $900 \mu \mathrm{L}$ ABTS radical 용액과 $100 \mu \mathrm{L}$ 시료를 혼합하여 실온에서 2분간 반응시킨 후, 분광 광도계(UV1800, Shimadzu, Kyoto, Japan)를 이용하여 734 $\mathrm{nm}$ 에서 흡광도를 측정하였다. 양성대조군으로는 a-tocopherol 을 사용하였다.

$$
\text { ABTS radical scavenging activity }(\%)=\left(1-\frac{\text { 시료의 흡광도 }}{\text { 대조구의 흡광도 }}\right) \times 100
$$

\section{통계처리}

모든 실험은 3 회 반복 수행하여 평균치와 표준편차로 나타내었으며, 실험군 간의 유의성 검증 및 상관성 분석은 SPSS(Statistical package for social sciences, SPSS Inc, Chicago, IL, USA) software(version 18.0)를 이용하여 실시 하였으며, 유의성 검증의 경우 ANOVA one way로 수행하 였다.

\section{결과 및 고찰}

\section{추출 방법에 따른 식물 잎의 총 폴리페놀 함량}

다양한 조건에서 추출한 녹차, 로즈마리, 레몬 잎, 조릿대 잎 추출물들의 폴리페놀 함량은 Fig. 1과 같다. 녹차의 경우 에는 에탄올 초음파 추출물, 증류수 가압 가열 추출물 및 증류수 상온 정치 추출물의 폴리페놀 함량이 다른 세 종류 의 식물 추출물들보다 높았으며, 특히 에탄올 초음파 추출 물의 폴리페놀 함량이 $43.72 \pm 4.83 \mathrm{mg} \mathrm{GAE} / \mathrm{g}$ 으로 가장 높았 다. 로즈마리의 경우에는 로즈마리 증류수 가압 가열 추출 물의 폴리페놀 함량이 $23.02 \pm 1.57 \mathrm{mg} \mathrm{GAE} / \mathrm{g}$ 으로 다른 로즈 마리 추출물과 비교하여 두드러지게 높은 폴리페놀 함량을 보였다. 레몬 잎과 조릿대 잎의 경우에는 각 추출물들의 폴리페놀 함량이 추출방법과 무관하게 약 $7.00 \mathrm{mg} \mathrm{GAE} / \mathrm{g}$ 이하로 측정되어 녹차와 로즈마리에 비해 상대적으로 낮은 폴리페놀 함량을 보였다. 식물에 함유되어 있는 페놀 화합

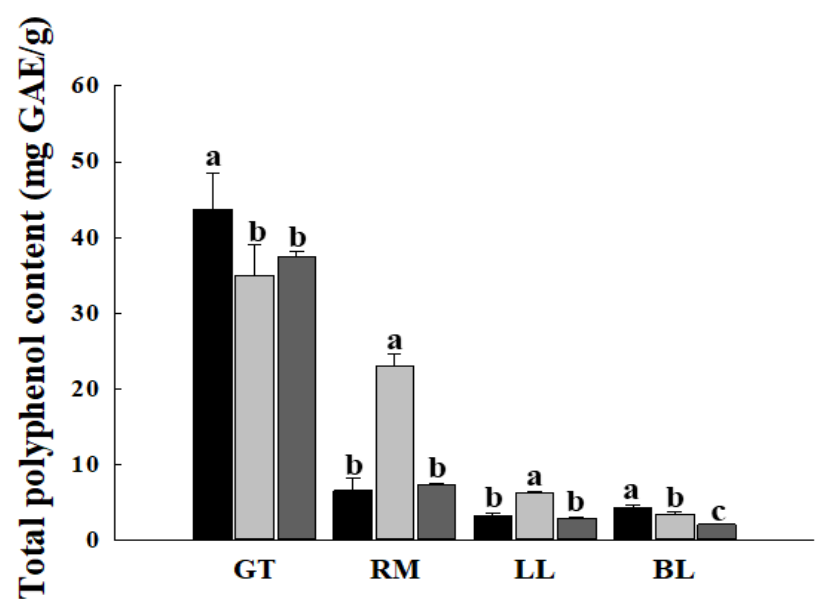

Fig. 1. Effect of extraction method on the total polyphenol content of plant extracts.

Each plant extract was prepared by $\square, 80 \%$ ethanol sonication extraction; $\square$, distilled water autoclave extraction; $\square$, distilled water extraction at room temperature. GAE, gallic acid equivalent.

GT, green tea; RM, rosemary; LL, lemon leaves; BL, bamboo leaves. Values are mean $\pm S D(n=3)$. Means with different letters among the same plant extracts are significantly different at $\mathrm{p}<0.01$. 
물은 다양한 항산화 활성과 생리활성을 가지며, 이는 분자 내 phenolic hydroxyl기가 효소 단백질 등 거대 분자들과 결합하는 특성이 있기 때문이라고 알려져 있다. 또한 페놀 화합물의 hydroxyl group은 유지 산패의 초기 단계에 생성 된 유리기들이 안정된 화합물을 형성할 수 있도록 산화억제 작용을 한다. 즉 페놀 함량이 높은 것은 산화 억제 작용이 높은 것을 의미한다(21). 이를 통해 레몬과 조릿대 잎보다는 녹차와 로즈마리 추출물에서 더 높은 항산화 활성을 기대할 수 있다.

\section{추출 방법에 따른 식물 잎의 총 플라보노이드 함량}

다양한 조건에서 추출한 녹차, 로즈마리, 레몬 잎, 조릿대 잎 추출물들의 플라보노이드 함량을 측정한 결과는 Fig. 2 와 같다. 녹차 추출물의 경우 에탄올 초음파 추출물, 증류 수 가압 가열 추출물, 증류수 상온 추출은 각각 $9.31 \pm 1.51$, $7.94 \pm 0.42,8.86 \pm 0.50 \mathrm{mg} \mathrm{RE} / \mathrm{g}$ 의 플라보노이드 함량을 보였 다. 한편 로즈마리 증류수 가압 가열 추출물의 플라보노이 드 함량은 $23.01 \pm 2.12 \mathrm{mg} \mathrm{RE} / \mathrm{g}$ 으로 녹차추출물보다 약 2 배 이상의 높은 플라보노이드 함량을 보였다. 레몬 잎과 조릿 대 잎의 경우에는 약 $3.00 \mathrm{mg} \mathrm{RE} / \mathrm{g}$ 이하의 낮은 플라보노이 드 함량을 보였다. 플라보노이드는 페놀성 화합물의 주된 성분이며, 세포를 공격하는 유리라디칼의 산화작용을 소거 하는 작용기를 포함하고 있다. 일반적으로 총 플라보노이 드 함량은 총 폴리페놀 함량과 밀접한 상관관계가 있다고 알려져 있으나(21), 본 연구 결과에서는 총 폴리페놀 함량이 가장 높았던 녹차 에탄올 초음파 추출물의 플라보노이드 함량이 로즈마리 증류수 가압 가열 추출물 보다 2 배 이상 낮게 나타났다. 이는 $\mathrm{Kim}$ 등(22)의 연구에서 쥐오줌풀의

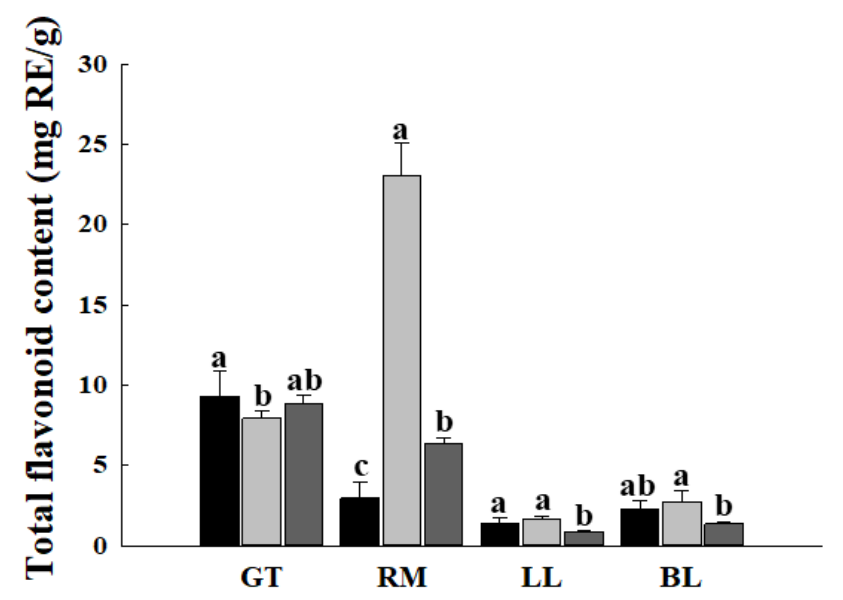

Fig. 2. Effect of extraction method on total flavonoid content of plant extracts.

Each plant extract was prepared by $\square, 80 \%$ ethanol sonication extraction; $\square$, distilled water autoclave extraction; $\square$, distilled water extraction at room temperature. $\mathrm{RE}$, rutin equivalent.

GT, green tea; RM, rosemary; LL, lemon leaves; BL, bamboo leaves.

Values are mean $\pm S D(n=3)$. Means with different letters among the same plant extracts are significantly different at $\mathrm{p}<0.01$.
플라보노이드 함량은 낮고 폴리페놀 함량이 높게 나타난 결과와 유사하며, 폴리페놀이 플라보노이드계와 비플라보 노이드계로 나누어지며 녹차 에탄올 초음파 추출물의 경우 플라보노이드계보다는 비플라보노이드계 폴리페놀의 함 량이 높았기 때문이라고 사료된다. 반면 로즈마리 증류수 가압 가열 추출물의 총 폴리페놀 함량은 총 플라보노이드 함량과 유사하게 나타났는데 이는 녹차 추출물과 달리 플라 보노이드계 폴리페놀의 함량이 녹차 에탄올 초음파 추출물 의 경우보다 상대적으로 높기 때문이라고 사료된다.

\section{추출 방법에 따른 식물 잎의 DPPH 라디칼 소거능 측정}

$\mathrm{DPPH}$ 라디칼의 경우 보라색의 안정한 자유 라디칼로서, 항산화 활성을 가진 물질과 만나면 환원되어 노란색으로 변하는 특징을 갖는다. 여러 연구에서 DPPH 라디칼의 색 변화를 이용하여 천연물질의 항산화 활성을 평가하는 지표 로 활용하고 있다(23). 본 실험에서는 측정한 다양한 추출물 의 DPPH 라디칼 소거능은 Fig. 3 에 나타낸 바와 같다. 녹차 추출물의 경우 추출방법과 상관없이 모두 높은 DPPH 라디 칼 소거능을 보였으며 그 중 에탄올 초음파 추출물에서 $86.87 \pm 4.81 \%$ 로 가장 높은 DPPH 라디칼 소거능을 보였다. 이는 $\mathrm{Gu}$ 등(21)이 해방풍 에탄올 초음파 추출물의 DPPH radical 소거능이 열수 추출물의 DPPH radical 소거능 보다 높다고 보고와 것과 유사한 양상이다. 로즈마리 추출물의 경우는 로즈마리 증류수 가압 가열 추출물에서 $50.07 \pm$ $2.54 \%$ 로 다른 추출방법과 비교하여 두드러지게 높은 $\mathrm{DPPH}$ 라디칼 소거능을 보였다. Lee 등(24)의 연구에서 로 즈마리 열수 추출 시 추출온도가 높을수록 높은 항산화 활성을 보인다는 보고가 있었으며, 이는 본 실험 결과와

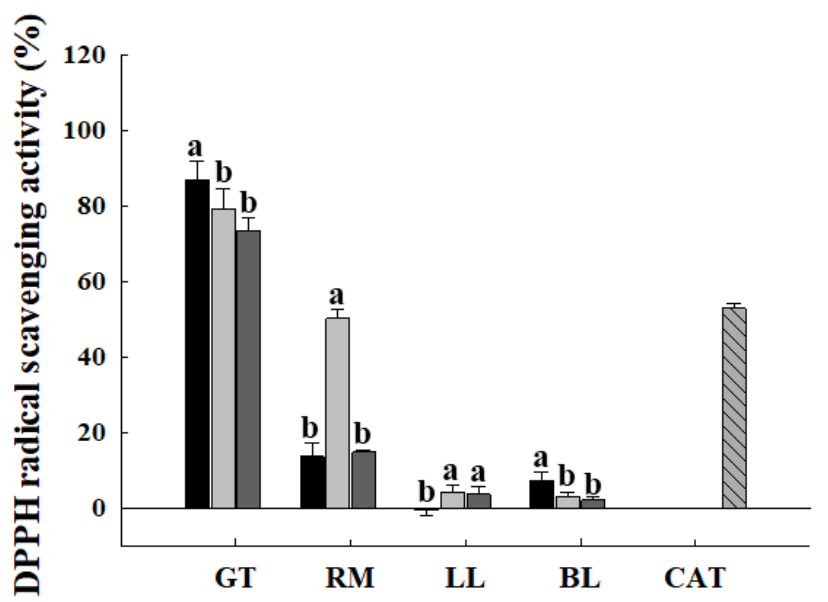

Fig. 3. Effect of extraction method on DPPH radical scavenging activity of plant extracts.

Each plant extract was prepared by $\square, 80 \%$ ethanol sonication extraction; $\square$, distilled water autoclave extraction; $\square$, distilled water extraction at room temperature and used at a concentration of $200 \mu \mathrm{g} / \mathrm{mL}$. M, catechin $200 \mu \mathrm{M}$ was used as a positive control. GT, green tea; RM, rosemary; LL, lemon leaves; BL, bamboo leaves. CAT, catechin. Values are mean $\pm S D(n=3)$. Means with different letters among the same plant extracts are significantly different at $\mathrm{p}<0.01$. 
일치하였다. 한편 Lee 등(24)의 연구에서는 로즈마리 열수 추출보다 에탄올 추출이 더 높은 항산화 활성을 보였으나 Cho 등(25)의 연구에서는 로즈마리 열수 추출물이 에탄올 초음파 추출물보다 높은 DPPH 라디칼 소거능을 보이고 있다. 이러한 차이는 추출용매는 동일하더라도 각 실험실 별로 추출방법의 차이에 의해 기인한 것으로 사료된다. 레 몬 잎과 조릿대 잎 추출물의 경우에는 모든 추출물에서 $10 \%$ 이하의 낮은 $\mathrm{DPPH}$ 라디칼 소거능을 보였다.

\section{ABTS 라디칼 소거능 측정}

$\mathrm{ABTS}$ 라디칼은 항산화 활성을 가진 물질에 의해 제거되 어 청록색이 하늘색으로 탈색되는 점을 이용한 측정방법으 로, hydrogen-donating antioxidants와 chain breaking antioxidants 모두 측정할 수 있다. 또한, aqueous phase와 organic phase 모두에 적용이 가능하다(26). 본 실험에서는 측정한 다양한 추출물의 ABTS 라디칼 소거능은 Fig. 4에 나타낸 바와 같다. 녹차 추출물의 경우 추출방법과 상관없 이 모두 높은 ABTS 라디칼 소거능을 보였으며, 녹차 에탄 올 초음파 추출물이 $99.95 \pm 0.24 \%$ 로 가장 높은 ABTS 라디 칼 소거능을 보였다. 로즈마리 추출물의 경우는 로즈마리 증류수 가압 가열 추출물에서 $37.49 \pm 0.90 \%$ 로 다른 추출방 법과 비교하여 높은 ABTS 라디칼 소거능을 보였다. 레몬과 조릿대 잎 추출물의 경우 추출방법과 관계없이 $10 \%$ 이하의 낮은 ABTS 라디칼 소거능을 보였다.

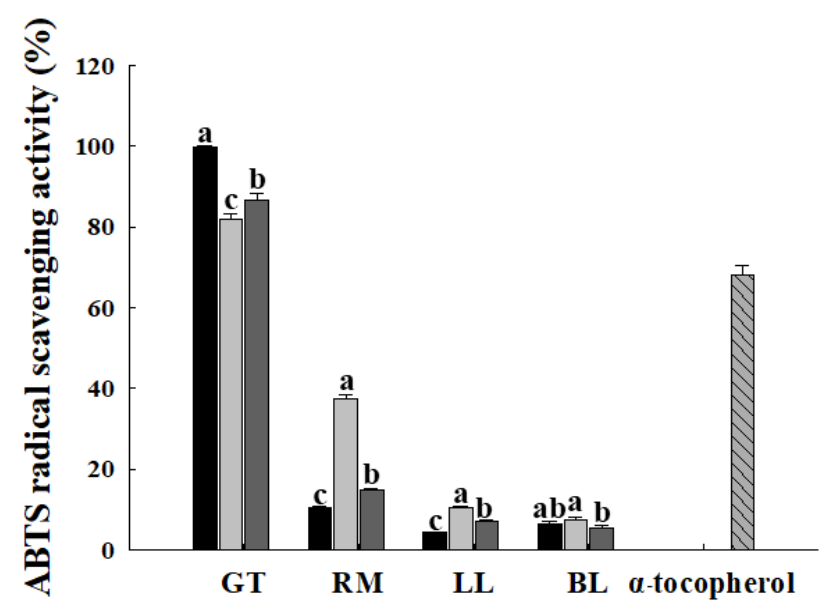

Fig. 4. Effect of extraction method on ABTS radical scavenging activity of plant extracts.

Each plant extract was prepared by $\square, 80 \%$ ethanol sonication extraction; $\square$, distilled water autoclave extraction; $\square$, distilled water extraction at room temperature and used at a concentration of $80 \mu \mathrm{g} / \mathrm{mL}$. II, a-tocopherol $200 \mu \mathrm{M}$ was used as a positive control.

GT, green tea; RM, rosemary; LL, lemon leaves; BL, bamboo leaves.

Values are mean \pm SD $(n=3)$. Means with different letters among the same plant extracts are significantly different at $\mathrm{p}<0.01$.

\section{상관관계 분석}

다양한 조건에서 추출한 녹차, 로즈마리, 레몬 잎, 조릿대 잎 추출물들의 항산화 물질과 항산화 활성간의 상관성을
비교한 결과는 Table 1 과 같다. 총 폴리페놀 함량과 총 플라 보노이드 간의 상관계수 $0.601(\mathrm{p}<0.05)$ 로 높은 상관성을 확인하였다. 또한 총 폴리페놀 함량과 DPPH 라디칼 소거 능, ABTS 라디칼 소거능의 경우 각각 $0.993(\mathrm{p}<0.01)$, $0.992(\mathrm{p}<0.01)$ 로 높은 상관관계를 나타내었다. 이는 Park 등(27)의 연구에서 총 폴리페놀 함량과 DPPH, ABTS 라디 칼 소거능 간의 상관계수 $0.860(\mathrm{p}<0.01), 0.943(\mathrm{p}<0.01)$ 와 유사한 수치이며, Joo(28)의 연구에서 총 폴리페놀 함량과 $\mathrm{DPPH}, \mathrm{ABTS}$ 라디칼 소거능의 상관계수 $0.551(\mathrm{p}<0.01)$, 0.489(p<0.01) 비해서는 높은 수치이다. 한편, 플라보노이 드 함량과 $\mathrm{DPPH}, \mathrm{ABTS}$ 라디칼 소거능의 상관관계 각각 $0.630(\mathrm{p}<0.05), 0.517$ 로 $\mathrm{Ku}$ 등(29)의 연구에서 보고한 상관 계수보다는 다소 낮게 나타났다. DPPH 라디칼 소거능과 ABTS 라디칼 소거능 간의 상관계수는 $0.987(\mathrm{p}<0.01)$ 으로 높은 상관성을 보였으며, 이는 여러 연구자들이 보고한 수 치(30)와 유사한 결과이다.

Table 1. Correlation coefficient between total polyphenol and flavonoid contents and antioxidant activities by DPPH, ABTS assay of plant extracts

\begin{tabular}{ccccc}
\hline & TPC $^{1)}$ & TFC & DPPH & ABTS \\
\hline TPC & 1.000 & & & \\
TFC & $0.601^{* 2}$ & 1.000 & & \\
DPPH & $0.993^{* *}$ & $0.630^{*}$ & 1.000 & \\
ABTS & $0.992^{* *}$ & $0.507^{\text {NS3) }}$ & $0.987^{* *}$ & 1.000 \\
\hline
\end{tabular}

${ }^{1)}$ TPC, total polyphenol contents; TFC, total flavonoid contents; DPPH, DPPH radical scavenging activity; ABTS, ABTS radical scavenging activity. 2)***, significant at $\mathrm{p}=0.05,0.01$. 3)'s', non significant.

녹차와 로즈마리 추출물을 첨가한 두유의 $\mathrm{DPPH}$ 라디칼 소거능 측정

네 가지 식물 중 항산화 활성이 높은 녹차와 로즈마리 추출물을 각각 $1 \%$ 와 $10 \%$ 첨가한 후 추출물이 첨가된 두유 의 DPPH 라디칼 소거능을 측정하였으며 이는 Fig. 5 와 같 다. 녹차 에탄올 초음파 추출물을 제외한 나머지 모든 추출 물에서 무첨가 두유와 비교하여 높은 DPPH 라디칼 소거능 을 보였다. 그 중에서 증류수 가압 가열과 상온에서 12 시간 정치한 녹차 추출물이 혼합된 두유의 DPPH 라디칼 소거능 이 다른 추출물에 비해 가장 우수하였다. 녹차 증류수 가압 가열 추출물을 $10 \%$ 첨가한 두유는 $85.1 \pm 2.3 \%$, 녹차 증류수 상온 정치 추출물을 $10 \%$ 첨가한 두유는 $84.4 \pm 2.0 \%$ 의 $\mathrm{DPPH}$ 라디칼 소거능을 보여 이들 두 추출물이 혼합된 두유 의 DPPH 라디칼 소거능에는 유의적 차이가 나타나지 않았 다(p<0.01). 폴리페놀 함량 및 DPPH 라디칼 소거능이 높은 녹차 에탄올 초음파 추출물을 첨가한 두유의 $\mathrm{DPPH}$ 라디칼 소거능은 무첨가 두유와 비교하여 오히려 낮은 소거능을 보였다. 이는 녹차 에탄올 초음파 추출물에는 녹차 증류수 
가압 가온 추출물이나 상온 정치 추출물에는 존재하지 않는 녹차 성분들이 침출되었을 가능성을 시사하고 있으며, 이 러한 성분들 중 일부가 두유와 혼합 시에 혼합 두유의 항산 화 효능을 저해하는 역할을 하는 것으로 판단된다. 한편, 로즈마리 가압 가열 추출물을 $10 \%$ 첨가한 두유의 $\mathrm{DPPH}$ 라디칼 소거능은 $74.7 \pm 6.6 \%$ 로 녹차 증류수 추출물에 이어 서 우수한 DPPH 라디칼 소거능을 보였다.

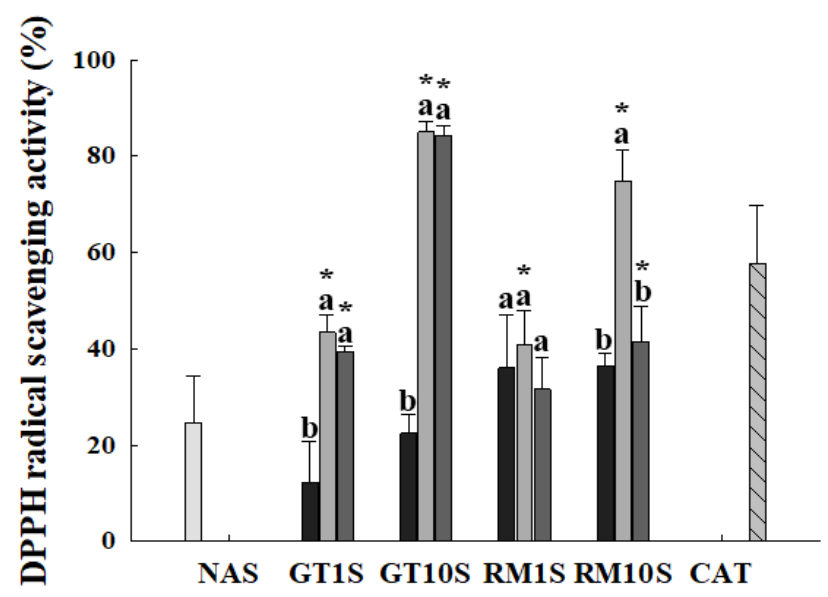

Fig. 5. DPPH radical scavenging activity of soymilk added with green tea and rosemary extracts.

Each extract was added to soymilk at $1 \%$ and $10 \%$. , NAS, non-added soymilk; _ 80\% ethanol sonication extract added soymilk; , distilled water autoclave extract added soymilk; $\square$, distilled water extract at room temperature added soymilk. $\square \backslash$, CAT, catechin $200 \mu \mathrm{M}$ was used as a positive control. GT1S, green tea $1 \%$ added soymilk; GT10S, green tea $1 \%$ added soymilk; RM1S, rosemary $1 \%$ added soymilk; RM10S, rosemary $10 \%$ added soymilk.

Values are mean $\pm S D(n=3)$. Means with different letters among the same plant extracts are significantly different at $p<0.01$. *Means indicated significant difference in comparing control (NAS) at $\mathrm{p}<0.01$.

녹차와 로즈마리 추출물을 첨가한 두유의 ABTS 라디칼 소거능 측정

각 추출물이 첨가된 두유를 사용하여 $\mathrm{ABTS}$ 라디칼 소거 능을 측정하였을 때 결과는 Fig. 6과 같다. 녹차 증류수 상온 정치 추출물과 증류수 가압 가열 추출물을 $10 \%$ 첨가 한 두유의 $\mathrm{ABTS}$ 라디칼 소거능이 가장 우수했으며 각각 $81.3 \pm 4.8 \%, 73.4 \pm 2.8 \% \mathrm{ABTS}$ 라디칼 소거능을 보였다. 녹 차 에탄올 초음파 추출물을 $1 \%, 10 \%$ 첨가한 두유에서는 각각 $10.2 \pm 2.6 \%, 27.0 \pm 3.9 \%$ 소거능을 보여 $48.1 \pm 4.2 \%$ 소거 능을 보인 무첨가 두유보다 ABTS 라디칼 소거능이 낮은 것을 확인할 수 있었다. 이는 DPPH 라디칼 소거능 결과와 도 유사한 것으로 녹차 에탄올 초음파 추출물을 두유에 혼합 시 ABTS 라디칼 소거능을 오히려 감소시키는 성분들 이 포함되어 있음을 시사하고 있다. 한편, 로즈마리 추출물 을 첨가한 두유의 $\mathrm{ABTS}$ 라디칼 소거능은 증류수 상온 정치 추출물을 $1 \%$ 첨가한 두유와 증류수 가압 가열 추출물을 $10 \%$ 첨가한 두유에서 무첨가 두유와 유의적 차이를 보였다 $(\mathrm{p}<0.01)$. 특이하게도, 로즈마리 증류수 가압 가열 추출물을
$10 \%$ 첨가한 두유의 $\mathrm{DPPH}$ 라디칼 소거능은 무첨가 두유보 다 월등하게 높았으나 로즈마리 증류수 가압 가열 추출물을 $10 \%$ 첨가한 두유의 $\mathrm{ABTS}$ 라디칼 소거능은 무첨가 두유와 비슷한 ABTS 라디칼 소거능을 보였다. 이는 ABTS 라디칼 소거능은 DPPH 라디칼과 달리 극성과 비극성 라디칼 모두 와 반응한 것에 기인한 것으로 사료된다. Lee 등(31)의 연구 에서 과채류를 식품에 첨가한 후 살균처리를 할 경우 살균 처리하기 전과 후의 $\mathrm{DPPH}$ 와 $\mathrm{ABTS}$ 라디칼 소거능의 차이 가 나타나지 않았다 보고하였으며, Choi 등(32)와 Dewant 등(33)의 연구에 따르면 열처리 과정에서 조직에 결합되어 있는 결합형 페놀화합물이 유리형 페놀화합물로 전환되어 폴리페놀, 플라보노이드 함량 및 항산화 활성이 오히려 증 가한다고 보고한 바 있다. 이러한 연구결과를 통해 두유 가공 시 로즈마리 추출물을 첨가한 후 살균을 할 경우에도 항산화 활성의 감소는 유발하지 않을 것으로 기대된다.

본 연구에서는 제주산 녹차, 로즈마리, 레몬 잎, 조릿대 잎을 물과 에탄올을 이용해 다양한 조건에서 추출물을 제조 하여 각 추출물에 대한 항산화 활성을 측정하였으며, 이 중 항산화 활성이 높은 식물 추출물을 두유에 첨가하였을 때 나타나는 항산화 활성에 대해 확인하였다. 로즈마리 추 출물을 첨가한 두유는 항산화 활성 증가를 바탕으로 두유 품질의 고급화와 두유 제품의 다양화에 기여할 것으로 기대 된다. 향후에는 로즈마리 추출물이 첨가된 두유의 항산화 활성뿐만 아니라, 생리활성 성분 분석과 관능검사, 항암 효능에 대한 연구를 통해 로즈마리 첨가두유의 가치를 더욱 증가시킬 수 있을 것으로 사료된다.

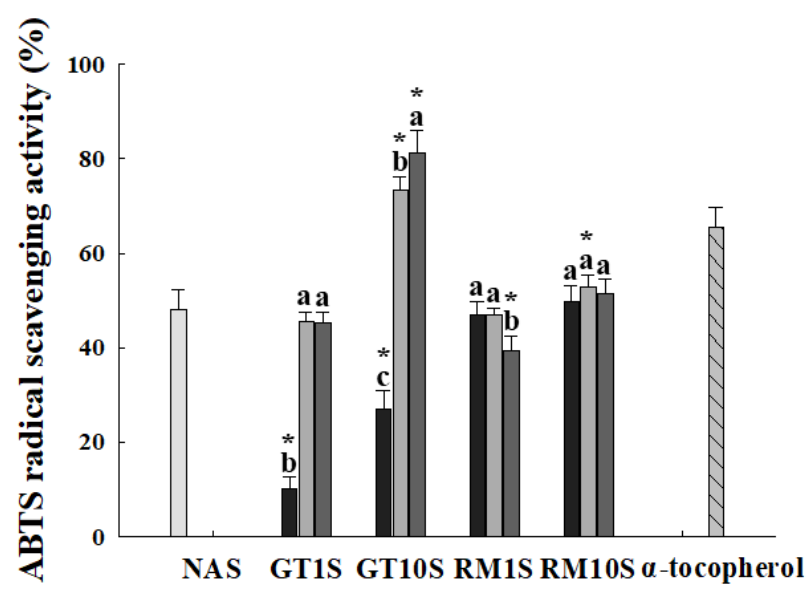

Fig. 6. ABTS radical scavenging activity of soymilk added with green tea and rosemary extracts.

Each extract was added to soymilk at $1 \%$ and $10 \%$. $\square$, NAS, Non-added soymilk; $\square$, $80 \%$ ethanol sonication extract added soymilk; $\quad$, distilled water autoclave extract added soymilk; $\square$, distilled water extract at room temperature added soymilk. $\square \square$, a-tocopherol $200 \mu \mathrm{M}$ was used as a positive control. GT1S, green tea $1 \%$ added soymilk; GT10S, green tea $1 \%$ added soymilk; RM1S, rosemary $1 \%$ added soymilk; RM10S, rosemary $10 \%$ added soymilk.

Values are mean \pm SD $(n=3)$. Means with different letters among the same plant extracts are significantly different at $p<0.01$. *Means indicated significant difference in comparing control (NAS) at $\mathrm{p}<0.01$. 


\section{요 약}

제주산 녹차, 로즈마리, 레몬 잎, 조릿대 잎을 물과 에탄 올을 이용해 다양한 조건에서 추출물을 제조하여 각 추출물 에 대한 항산화 활성을 측정하였다. 그 결과, 녹차와 로즈마 리 추출물이 레몬과 조릿대 잎 추출물과 비교하여 상대적으 로 높은 항산화 활성을 보였다.

항산화 활성이 상대적으로 우수한 녹차와 로즈마리 추출 물들을 두유에 첨가한 뒤, 혼합물의 항산화 활성을 측정하 였다. 녹차 증류수 가압 가열 추출물과 상온 정치 추출물 $10 \%$ 첨가한 두유에서 상대적으로 가장 높은 활성을 보였으 며, 녹차 증류수 가압 가열 추출물과 상온 정치 추출물의 $\mathrm{DPPH}$ 라디칼 소거능은 각각 $85.1 \pm 2.3 \%, 84.4 \pm 2.0 \%$ 을, $\mathrm{ABTS}$ 라디칼 소거능은 각각 $73.4 \pm 2.8 \%, 81.3 \pm 4.8 \%$ 로 확인 되었다. 한편, 로즈마리 증류수 가압 가열 추출물 $10 \%$ 첨가 한 두유에서 무첨가 두유에 비해 더 높은 $\mathrm{DPPH}$ 라디칼 소거능이 확인되었으며, $\mathrm{ABTS}$ 라디칼 소거능은 무첨가 두유와 유사했다. 따라서 녹차 증류수 가압 가열추출물과 상온 정치 추출물, 그리고 로즈마리 증류수 가압 가열 추출 물을 두유에 첨가 시 항산화 활성이 향상된 고부가가치 두유제품 개발 제발이 가능할 것으로 기대된다.

\section{감사의 글}

본 연구는 제주대학교 친환경농업연구소 실험 기관시설 이 수행에 활용되었으며 중소기업청에서 지원하는 2016년 도 산학연협력 기술개발사업(No.C0438577)의 연구수행으 로 인한 결과물임을 밝힙니다.

\section{References}

1. Barnes S, Peterson TG, Coward L (1995) Rationale for the use of genistein-containing soy matrices in chemoprevention trials for breast and prostate cancer. $\mathbf{J}$ Cell Biochem, 59, 181-187

2. Yang M, Kwak JS, Jang SR, Jia Y, Park IS (2013) Antioxidant activity of soybean yogurt added tomato extract by Bacillus subtilis and Lactobacillus plantarum. Korean J Food Nutr, 26, 280-286

3. Pyun JW, Hwang IK (1996) Preparation of calciumfortified soymilk and in vitro digestion properties of its protein and calcium. Korean J Food Sci Technol, 28, 995-1000

4. Kim JH, Choi JM, Cho EJ (2010) Antioxidative activity of purple sweet potato extract-added soymilk fermented with Bacillus subtilis. Cancer Prev Res, 15, 92-98

5. Lee LS, Jung KH, Choi UK, Hong HD, Kim YC (2013) Ginsenosides composition and antioxidant activities of fermented ginseng soymilk. J Korean Soc Food Sci Nutr, 42, 1533-1538

6. Kim DK, Choi EJ, Kim CH, Kim YB, Kim EM, Kum JS, Park JD (2014) Physicochemical properties of rice grain-added soymilk. J Korean Soc Food Sci Nutr, 43, 1278-1282

7. Choi SN, Joo MK, Chung NY (2014) Quality characteristics of soybean milk added with stevia leaf powder. J Korean Diet Assoc, 20, 77-86

8. Jeong DH, Kim CJ (2015) Preparation and quality characteristics of soymilk added with buckwheat sprout. J Korean Soc Food Cult, 30, 77-85

9. Yu MH, Chae IG, Jung YT, Jeong YS, Kim HI, Lee IS (2011) Antioxidative and antimicrobial activities of methanol extract from Rosmarinus offcinalis L. and their fractions. J Life Sci, 21, 375-384

10. Chae IG, Kim HJ, Yu MH, Kim HI, Lee IS (2010) Antioxidant and antibacterial activity of commercially available herbs in Korean markets. J Korean Soc Food Sci Nutr, 39, 1411-1417

11. Lee JH, Kim Y, Lee SY, Yoo SH (2014) Conditions for obtaining optimum polyphenol contents and antioxidant activities of Korean berry and green tea extracts. Korean J Food Sci Technol, 46, 410-417

12. Yoon JH, Lee J, Oh CK, Chen Z, Yang SY, Song WS (2006) Effect of plant growth regulator on antioxidant activity of Rosemarinus officinalis L. and Lavandula spica L.. Korean J Plant Res, 19, 315-322

13. Kim JH, Kim MJ, Choi SK, Bae SH, An SK, Yoon YM (2011) Antioxidant and antimicrobial effects of lemon and eucalyptus essential oils against skin floras. J Soc Cosmet Scientistis Korea, 37, 303-308

14. Kang JW, Chang JP, Yoo JH, Doh ES, Kil KJ (2016) Antioxidant activities of extracts from different parts of Sasa borealis. Kor J Herbol, 31, 45-52

15. Cheung LM, Cheung PCK, Ooi VEC (2003) Antioxidant activity and total phenolics of edible mushroom extracts. Food Chem, 81, 249-255

16. Zhishen J, Mengcheng T, Jianming W (1999) The determination of flavonoid contents in mulberry and their scavenging effects on superoxide radicals. Food Chem, 64, 555-559

17. Blois MS (1958) Antioxidant determinations by the use of a stable free radical. Nature, 181, 1199-1200 
18. Brand-Williams W, Cuvelier ME, Berset C (1995) Use of a free radical method to evaluate antioxidant activity. LWT-Food Sci Technol, 28, 25-30

19. Ahn CB, Jeon YJ, Kang DS, Shin TS, Jung BM (2004) Free radical scavenging activity of enzymatic extracts from a brown seaweed Scytosiphon lomentaria by electron spin resonance spectrometry. Food Res Int, 37, 253-258

20. Re R, Pellegrini N, Proteggente A, Pannala A, Yang M, Rice-Evans C (1999) Antioxidant activity applying an improved ABTS radical cation decolorization assay. Free Radical Biol Med, 26, 1231-1237

21. Gu YR, Kim SW, Son YW, Hong JH (2017) Antioxidant activities of solvent extracts from different Glehnia Radix parts and their inhibitory effect against nitric oxide production in Raw 264.7 cell. Korean J Food Preserv, 24, 116-124

22. Kim EJ, Choi JY, Yu MR, Kim MY, Lee SH, Lee BH (2012) Total polyphenols, total flavonoid contents, and antioxidant activity Korean natural and medicinal plants. Korean J Food Sci Technol, 44, 337-342

23. Kang HR, Koh SY, Ryu JY, Osman A, Lee CK, Lim JH, Kim HA, Im GH, Cho SMK (2016) Antioxidant activities and physicochemical properties of chocolate fermented by Lactobacillus plantarum CK10. Korean J Food Preserv, 23, 576-584

24. Lee CY, Kim KM, Son HS (2013) Optimal extraction conditions to produce rosemary extracts with higher phenolic content and antioxidant activity. Korean J Food Sci Technol, 45, 501-507

25. Cho YJ, Kim JH, Yoon SJ, Chun SS, Choi UK (2005) Studies on the biological activity of Rosemarinus officinalis L.. Korean J Food Sci Technol, 37, 970-975
26. Jin DE, Kim HJ, Jeong JH, Jo YN, Kwon OJ, Choi SG, Heo HJ (2014) Nutritional components of Zespri green kiwi fruit (Actinidia delicosa) and neuronal cell protective effects of the n-hexane fraction. Korean J Food Sci Technol, 46, 369-374

27. Park GH, Lee SH, Kim HY, Jeong HS, Kim EY, Yun YW, Nam SY, Lee BJ (2011) Comparison in antioxidant effects of four citrus fruits. J Food Hyg Saf, 26, 355-360

28. Joo SY (2013) Antioxidant activities of medicinal plant extracts. J Korean Soc Food Sci Nutr, 42, 512-519

29. Ku KM, Kim HS, Kim BS, Kang YH (2009) Antioxidant activities and antioxidant constituents of pepper leaves from various cultivars and correlation between antioxidant activities and antioxidant constituents. J Appl Biol Chem, 52, 70-76

30. Kim MH, Jeong EJ, Kim YS (2016) Studies on the antioxidative activities and active components of the extracts from Pleurotus ostreatus. J Food Hyg Saf, 31, 119-125

31. Lee HJ, Kim SJ, Bang E, Shin HH, Cho HY (2016) Effects of cooking method and pasteurization treatment on instant thin rice porridge added with fruits and vegetables. J Korean Soc Food Sci Nutr, 45, 569-576

32. Choi JH, Yim SH, Choi JJ, Kim SJ, Nam SH, Kang SS, Kim YK, Lee HC (2013) Easy production techniques for clear pear juice and its antioxidant activities of 'Chuwhangbae' pear. 20, 720-726

33. Dewanto V, Wu X, Adom KK, Liu RH (2002) Thermal processing enhances the nutritional value of tomatoes by increasing total antioxidant activity. J Agric Food Chem, 50, 3010-3014 